\title{
HUBUNGAN STATUS GIZI DAN TEKANAN DARAH DENGAN KADAR C-REACTIVE PROTEIN DARAH PADA SUBJEK DISLIPIDEMIA
}

\author{
(Association of Nutritional Status and Blood Pressure with Blood C-Reactive Protein Level in \\ Dyslipidemic Subjects)
}

\author{
Mira Dewi ${ }^{1 *}$, Rimbawan $^{1}$, dan Agustino ${ }^{1}$ \\ 'Departemen Gizi Masyarakat, Fakultas Ekologi Manusia (FEMA), Institut Pertanian Bogor, Bogor 16680
}

\begin{abstract}
The objective of this study was to analyze the association of nutritional status (Body Mass Index, waist circumference, waist-hip ratio, and body fat mass) and blood pressure with inflammation status which was assessed by blood C-reactive protein level in dyslipidemic subjects. The study design was cross sectional survey involving 81 dyslipidemic subjects in Bogor. The study showed that there were significant correlations between BMI, waist-hip ratio, body fat mass, and diastolic blood pressure with blood CRP level $(p<0.05)$. In conclusion, the higher percentage of over nutritional status, body fat mass, and diastolic blood pressure, the higher status of inflammation.
\end{abstract}

Keywords: blood pressure, body fat mass, C-reactive protein, dyslipidemia, nutritional status

\begin{abstract}
ABSTRAK
Tujuan penelitian ini adalah untuk menganalisis hubungan status gizi berdasarkan Indeks Massa Tubuh (IMT), lingkar pinggang, rasio lingkar pinggang pinggul dan persen lemak tubuh serta tekanan darah dengan status inflamasi yang ditentukan dengan kadar C-reactive protein (CRP) darah pada subjek dislipidemia. Desain penelitian adalah survei potong lintang, melibatkan 81 subjek penderita dislipidemia di wilayah Kota dan Kabupaten Bogor. Hasil penelitian menunjukkan bahwa terdapat hubungan signifikan antara IMT, rasio lingkar pinggang pinggul, persentase lemak tubuh, serta tekanan darah diastolik dengan kadar CRP darah $(p<0.05)$. Disimpulkan bahwa pada subjek penderita dislipidemia, semakin tinggi persentase status gizi lebih, massa lemak tubuh, dan tekanan darah diastolik semakin tinggi pula status inflamasinya.
\end{abstract}

Kata kunci: C-reactive protein, dislipidemia, massa lemak tubuh, status gizi, tekanan darah

"Korespondensi: Departemen Gizi Masyarakat, Fakultas Ekologi Manusia (FEMA), Institut Pertanian Bogor, Bogor 16680. Email: miradewi2010@gmail.com 
Dewi dkk.

\section{PENDAHULUAN}

Dislipidemia merupakan suatu kondisi ketidaknormalan profil lipid yang dicirikan dengan meningkatnya kadar trigliserida (TGA), kolesterol total, kolesterol low density lipoprotein (LDL), atau rendahnya kolesterol high density lipoprotein (HDL) (Osuji et al. 2010). Dislipidemia merupakan salah satu faktor risiko penyakit kardiovaskular (Genest et al. 2003). Kondisi gangguan profil lipid tersebut memicu terjadinya proses inflamasi di dalam tubuh dalam proses aterosklerosis. Luka anterosklerotik akan memicu pembentukan sel sitokin proinflamasi. Peningkatan sel sitokin akan memicu terjadinya peningkatan indikator-indikator inflamasi, salah satunya adalah $\mathrm{C}$-reactive protein (CRP) (Pearson et al. 2003).

CRP merupakan indikator inflamasi terbaik dibandingkan dengan yang lainnya seperti interleukin-1 (IL-1), interleukin-6 (IL-6), lipoprotein-associated phospholipase A2 (Lp-PLA2), dan Mieloperoksidase (MPO) (Blake \& Ridker 2003). CRP diproduksi di hati untuk merespon peningkatan interleukin-6 (salah satu sitokin dalam tubuh) dan terbukti dapat memprediksikan penyakit kardiovaskular (Pepys \& Hirschfield 2003).

Dislipidemia berhubungan terhadap status gizi dan tekanan darah pada seseorang. Studi oleh Liu et al. (2010) menunjukkan bahwa kegemukan lebih banyak terjadi pada individu yang mengalami dislipidemia. Di samping itu, kondisi dislipidemia akan menyebabkan kerusakan pada endotel dan berkurangnya aktivitas vasomotor (Boos \& Lip 2006) sehingga meningkatkan tekanan darah. Studi cross-sectional menunjukkan adanya hubungan dislipidemia dengan kejadian hipertensi (Oparil et al. 2003).

Studi mengenai CRP terhadap status gizi dan tekanan darah pada subjek terbatas tertentu seperti dislipidemia masih belum banyak dikaji. Oleh karena itu, penelitian ini dilakukan untuk mengkaji hubungan antara kadar CRP darah terhadap status gizi dan tekanan darah pada subjek dislipidemia. Tujuan umum dalam penelitian ini adalah mengkaji hubungan status gizi dan tekanan darah terhadap CRP pada subjek dislipidemia.

\section{METODE}

\section{Desain, Tempat, dan Waktu}

Desain penelitian adalah cross-sectional dan dilakukan pada bulan Oktober-Desember 2012 di wilayah Kota dan Kabupaten Bogor. Penelitian ini menggunakan sebagian data baseline penelitian utama yang berjudul "Efficacy study on plant sterol-enriched palm oil intervention to improve lipid profile and inflammation status in hyperlipidaemic individuals". Penelitian ini telah memperoleh persetujuan etik dengan nomor surat persetujuan etik 333/EC/FK/RSDK/2012.

\section{Jumlah dan Cara Penarikan Subjek}

Jumlah subjek dalam penelitian ini sebanyak 81 subjek. Penarikan subjek dilakukan secara purposif dengan kriteria pria atau wanita dewasa berusia 20-67 tahun, wanita tidak sedang hamil, dislipidemia (TGA $\geq 150 \mathrm{mg} / \mathrm{dL}$, kolesterol total $\geq 200$ $\mathrm{mg} / \mathrm{dL}$, kolesterol $\mathrm{LDL} \geq 130 \mathrm{mg} / \mathrm{dL}$, atau kolesterol $\mathrm{HDL}<40 \mathrm{mg} / \mathrm{dL}$ ) (National Institute of Health $(\mathrm{NIH})$ 2001), tidak mengonsumsi obat-obatan hipertensi atau penurun kolesterol, tidak menderita penyakit jantung, diabetes, ginjal atau penyakit kronik lainnya, dan bersedia menjadi subjek dalam penelitian ini.

\section{Jenis dan Cara Pengumpulan Data}

Data primer meliputi tekanan darah (tekanan sistolik dan tekanan diastolik). Data sekunder meliputi karakteristik sosial ekonomi (jenis kelamin dan umur), status gizi (Indeks Massa Tubuh (IMT), Lingkar Pinggang (LP), Rasio Lingkar Pinggang Pinggul (RLPP), dan persentase lemak tubuh), profil lipid darah (TGA, kolesterol total, kolesterol LDL, dan kolesterol $\mathrm{HDL}$ ) dan indikator inflamasi (CRP).

IMT diperoleh melalui berat badan dan tinggi badan. Berat badan diukur menggunakan timbangan injak (ketelitian $0.1 \mathrm{~kg}$ ) dan pengukuran tinggi badan menggunakan microtoise (ketelitian $0.1 \mathrm{~cm}$ ). Lingkar pinggang dan lingkar pinggul diukur menggunakan meterline (ketelitian $0.1 \mathrm{~cm}$ ). Persentase lemak tubuh diukur menggunakan alat Body Fat Monitoring (Ketelitian 4.1\% dengan kisaran 4.0-50.0\%). Data tekanan darah subjek diperoleh dengan menggunakan alat automatic blood pressure monitor (ketelitian $\pm 3 \mathrm{mmHg}$ dengan kisaran 0-299 $\mathrm{mmHg}$ ).

Darah diambil dari pembuluh darah vena pada lipatan siku lengan sebanyak $5 \mathrm{~mL}$. Pengambilan darah dilakukan pada pagi hari sekitar pukul 07.0008.00 WIB pada subjek yang telah puasa minimal delapan jam sebelumnya. Profil lipid darah dianalisis menggunakan metode spektrofotometri. Kadar CRP dianalisis menggunakan metode particle enhanced immunoturbidimetric assay. Analisis profil lipid darah dan CRP dilakukan oleh laboratorium Prodia ${ }^{\circledR}$ Kota Bogor.

\section{Pengolahan dan Analisis Data}

Usia subjek dikelompokkan berdasarkan Papalia \& Olds (2001) menjadi dewasa awal (20-40 tahun), dewasa madya (41-65 tahun), dan dewasa lanjut (>65 tahun). IMT dikelompokkan menjadi kurus $\left(<18.5 \mathrm{~kg} / \mathrm{m}^{2}\right)$, normal $\left(18.5-22.9 \mathrm{~kg} / \mathrm{m}^{2}\right)$, overweight $\left(23.0-24.9 \mathrm{~kg} / \mathrm{m}^{2}\right)$, obesitas I $(25.0-29.9 \mathrm{~kg} /$ $\left.\mathrm{m}^{2}\right)$, dan obesitas II $\left(\geq 30.0 \mathrm{~kg} / \mathrm{m}^{2}\right)$ (WHO 2000). Data persentase lemak tubuh diolah dan dikelompokkan berdasarkan Gallagher et al. (2000) pada Tabel 1. 
Tabel 1. Kategori Persentase Lemak Tubuh Populasi Asia menurut Gallagher et al. (2000)

\begin{tabular}{cccccc}
\hline \multirow{2}{*}{ Jenis Kelamin } & \multirow{2}{*}{ Usia (Tahun) } & \multicolumn{4}{c}{ Kategori Persentase Lemak Tubuh (\%) } \\
\cline { 3 - 6 } & & Rendah & Normal & Tinggi & Sangat Tinggi \\
\hline \multirow{2}{*}{ Pria } & $20-39$ & $<13.0$ & $13.0-22.9$ & $23.0-27.9$ & $\geq 28.0$ \\
& $40-59$ & $<13.0$ & $13.0-23.9$ & $24.0-28.9$ & $\geq 29.0$ \\
& $60-79$ & $<13.0$ & $14.0-23.9$ & $24.0-28.9$ & $\geq 29.0$ \\
\multirow{3}{*}{ Wanita } & $20-39$ & $<25.0$ & $25.0-34.9$ & $35.0-39.5$ & $\geq 40.0$ \\
& $40-59$ & $<25.0$ & $25.0-34.9$ & $35.0-40.9$ & $\geq 41.0$ \\
& $60-79$ & $<25.0$ & $25.0-35.9$ & $36.0-40.9$ & $\geq 41.0$ \\
\hline
\end{tabular}

LP dikelompokkan dengan batas $>90 \mathrm{~cm}$ berisiko komplikasi metabolik untuk pria dan $>80 \mathrm{~cm}$ berisiko komplikasi metabolik untuk wanita (Grundy et al. 2005). RLPP dikelompokkan berdasarkan WHO (2008) yaitu RLPP $\geq 0.90$ berisiko komplikasi metabolik bagi pria dan RLPP $\geq 0.85$ berisiko komplikasi metabolik bagi wanita.

Tekanan darah dikelompokkan berdasarkan tekanan sistolik dan diastolik berdasarkan Joint $\mathrm{Na}$ tional Committee VII (JNC VII) (2004) yaitu normal $(<120 / 80 \mathrm{mmHg})$, prehipertensi $(120-139 / 80-89$ $\mathrm{mmHg}$ ), hipertensi I (140-159/90-99 mmHg), dan hipertensi II ( $\geq 160 / 100 \mathrm{mmHg})$. Data CRP dikategorikan menurut Pearson et al. (2003) yaitu $<1.0$ $\mathrm{mg} / \mathrm{L}$ risiko rendah, $1-3 \mathrm{mg} / \mathrm{L}$ risiko sedang, $>3$ $\mathrm{mg} / \mathrm{L}$ risiko tinggi terhadap penyakit kardiovaskular. Penyakit inflamasi kronik biasanya $\leq 10.0 \mathrm{mg} / \mathrm{L}$, apabila $>10.0 \mathrm{mg} / \mathrm{L}$ merupakan indikasi adanya infeksi yang seharusnya dieksklusi.

Pengolahan dan analisis data menggunakan Microsoft Excel 2007 dan Minitab ${ }^{\circledR}$ 15.1.20.0. Analisis data yang digunakan adalah deskriptif dan inferensia. Analisis secara deskriptif (rata-rata, persentase, dan standar deviasi) digunakan untuk menganalisis karakteristik sosial ekonomi subjek, status gizi, tekanan darah, dan kadar CRP. Analisis inferensia yang digunakan adalah uji regresi linier berganda untuk menguji hubungan status gizi dan tekanan darah terhadap kadar CRP.

\section{HASIL DAN PEMBAHASAN}

\section{Karakteristik Subjek}

Sebagian besar subjek adalah wanita yaitu sebanyak $75.3 \%$ dan $24.7 \%$ adalah pria. Rata-rata usia subjek adalah $48 \pm 9$ tahun. Sebagian besar subjek berada pada kategori dewasa madya yaitu 41-65 tahun (77.8\%). Subjek yang termasuk kategori dewasa awal sebesar $19.7 \%$ dan kategori dewasa lanjut hanya $2.5 \%$.

\section{Profil Lipid Darah Subjek}

Sebaran subjek menurut rata-rata kadar TGA, kolesterol total, kolesterol LDL, dan kolesterol HDL ditampilkan pada Tabel 2. Secara total, rata-rata kadar TGA, kolesterol total, dan kolesterol HDL tidak normal. Berdasarkan jenis kelamin, rata-rata lipid darah yang abnormal pada pria adalah kadar TGA dan kolesterol HDL. Hal ini dapat disebabkan oleh faktor obesitas, aktivitas fisik yang rendah, dan seringnya konsumsi makanan tinggi gula dan lemak seperti jeroan (Krummel di dalam Mahan \& Stump 2008). Pada wanita, abnormalitas terjadi pada kadar TGA, kolesterol total, dan kolesterol LDL. Hal ini dapat disebabkan oleh faktor obesitas, rendahnya aktivitas fisik, berkurangnya hormon estrogen (pasca-menopause), dan seringnya konsumsi makanan tinggi lemak (Krummel di dalam Mahan \& Stump 2008).

Tabel 2. Rata-rata Kadar TGA, Kolesterol Total, Kolesterol LDL, dan Kolesterol HDL menurut jenis kelamin

\begin{tabular}{lccc}
\hline \multicolumn{1}{c}{$\begin{array}{c}\text { Fraksi Lipid } \\
\text { Darah }(\mathrm{mg} / \mathrm{dL})\end{array}$} & \multicolumn{2}{c}{ Jenis Kelamin } & \multirow{2}{*}{ Total } \\
\cline { 2 - 3 } & Pria & Wanita & \\
\hline TGA & $191 \pm 93$ & $151 \pm 69$ & $161 \pm 77$ \\
Kolesterol Total & $194 \pm 30$ & $230 \pm 28$ & $221 \pm 32$ \\
Kolesterol LDL & $124 \pm 30$ & $153 \pm 27$ & $146 \pm 30$ \\
Kolesterol HDL & $37 \pm 6$ & $49 \pm 8$ & $46 \pm 9$ \\
\hline
\end{tabular}

Status Gizi Subjek Berdasarkan Antropometri Gizi

Sebaran subjek menurut antropometri gizi ditampilkan pada Tabel 3. Sebagian besar subjek memiliki IMT di atas batas normal yakni sekitar 83.9\% (overweight, obesitas I, dan obesitas II). Persentase wanita yang mengalami kegemukan (overweight dan obesitas) (85.3\%) lebih tinggi dibandingkan dengan pria $(80.0 \%)$. Hal ini dapat disebabkan oleh faktor rendahnya aktivitas fisik dan kurangnya konsumsi serat yang sering terjadi pada wanita dibandingkan dengan pria (Krummel di dalam Mahan \& Stump 2008). Persentase wanita yang memiliki aktivitas fisik rendah dan kurang konsumsi buah dan sayur lebih tinggi dibandingkan dengan wanita (Depkes 2008). Rata-rata IMT wanita $\left(28.2 \pm 4.9 \mathrm{~kg} / \mathrm{m}^{2}\right)$ lebih besar dibandingkan dengan pria $\left(25.9 \pm 3.5 \mathrm{~kg} / \mathrm{m}^{2}\right)$.

Sebagian besar subjek berisiko komplikasi metabolik yakni sebesar $87.7 \%$. Rata-rata LP wanita $(94.4 \pm 9.1 \mathrm{~cm})$ lebih besar dibandingkan dengan pria $(91.8 \pm 10.0 \mathrm{~cm})$ dan persentase wanita yang memiliki LP berisiko komplikasi metabolik (95.1\%) lebih 
Dewi dkk.

Tabel 3. Sebaran Subjek menurut Antropometri Gizi

\begin{tabular}{|c|c|c|c|}
\hline \multirow{2}{*}{ Antropometri Gizi } & \multicolumn{2}{|c|}{ Jenis Kelamin } & \multirow{2}{*}{ Total n (\%) } \\
\hline & Pria n (\%) & Wanita n (\%) & \\
\hline \multicolumn{4}{|l|}{ Indeks Massa Tubuh: } \\
\hline Normal & $4(20.0)$ & $9(14.7)$ & $13(16.1)$ \\
\hline Overweight & $4(20.0)$ & $8(13.1)$ & $12(14.8)$ \\
\hline Obesitas I & $10(50.0)$ & $22(36.1)$ & $32(39.5)$ \\
\hline Obesitas II & $2(10.0)$ & $22(36.1)$ & $24(29.6)$ \\
\hline Total & $20(100.0)$ & $61(100.0)$ & $81(100.0)$ \\
\hline Rata-rata \pm std $\left(\mathrm{kg} / \mathrm{m}^{2}\right)$ & $25.9 \pm 3.5$ & $28.2 \pm 4.9$ & $27.7 \pm 4.7$ \\
\hline \multicolumn{4}{|l|}{ Lingkar Pinggang: } \\
\hline Normal & $7(35.0)$ & $3(4.9)$ & $10(12.3)$ \\
\hline Berisiko komplikasi metabolik & $13(65.0)$ & $58(95.1)$ & $71(87.7)$ \\
\hline Total & $20(100.0)$ & $61(100.0)$ & $81(100.0)$ \\
\hline Rata-rata \pm std $(\mathrm{cm})$ & $91.8 \pm 10.0$ & $94.4 \pm 9.1$ & $93.8 \pm 9.3$ \\
\hline \multicolumn{4}{|l|}{ Rasio Lingkar Pinggang Pinggul: } \\
\hline Normal & $2(10.0)$ & $6(9.8)$ & $8(9.9)$ \\
\hline Berisiko komplikasi metabolik & $18(90.0)$ & $55(90.2)$ & $73(90.1)$ \\
\hline Total & $20(100.0)$ & $61(100.0)$ & $81(100.0)$ \\
\hline Rata-rata \pm Std & $0.92 \pm 0.11$ & $0.92 \pm 0.06$ & $0.92 \pm 0.08$ \\
\hline \multicolumn{4}{|l|}{ Persentase Lemak Tubuh: } \\
\hline Rendah & $0(0.0)$ & $1(1.7)$ & $1(1.2)$ \\
\hline Normal & $2(10.0)$ & $31(50.8)$ & $33(40.8)$ \\
\hline Tinggi & $8(40.0)$ & $18(29.5)$ & $26(32.1)$ \\
\hline Sangat tinggi & $10(50.0)$ & $11(18.0)$ & $21(25.9)$ \\
\hline Total & $20(100.0)$ & $61(100.0)$ & $81(100.0$ \\
\hline Rata-rata \pm std $(\%)$ & $28.1 \pm 4.0$ & $35.3 \pm 5.2$ & $33.5 \pm 5.8$ \\
\hline
\end{tabular}

tinggi dibandingkan dengan pria (65.0\%). Menurut Gee et al. di dalam Mahan \& Stump (2008), wanita cenderung memiliki pola penumpukan jaringan lemak pada abdominal seperti halnya dengan pria, pada saat wanita pasca-menopause. Sebagian besar subjek dalam penelitian ini berada pada kategori dewasa madya (40-65 tahun), dimana wanita dalam rentang usia tersebut cenderung telah mengalami menopause.

Sebagian besar subjek memiliki RLPP di atas batas normal yakni $90.1 \%$ subjek. Pria dan wanita memiliki rata-rata RLPP sama besar $(0.92 \pm 0.11$ dan $0.92 \pm 0.06)$. Persentase pria dan wanita yang berisiko komplikasi metabolik hampir sama besar, masingmasing yaitu sebesar $90.0 \%$ dan $90.2 \%$.

Sebagian besar subjek memiliki persentase lemak tubuh di atas batas normal, yakni sekitar $58.0 \%$ (kategori tinggi dan sangat tinggi). Rata-rata persentase lemak tubuh wanita $(35.3 \pm 5.2 \%)$ lebih tinggi dibandingkan dengan pria $(28.1 \pm 4.0 \%)$. Akan tetapi, persentase pria yang memiliki persentase lemak tubuh di atas batas normal (90.0\%) lebih tinggi dibandingkan dengan wanita (47.5\%). Jika dibandingkan dengan IMT, LP, dan RLPP yang cenderung lebih tinggi pada wanita, hal ini dapat diduga adanya distribusi lemak yang tinggi juga pada bagian tubuh lainnya pada pria sehingga berdasarkan batas persentase lemak tubuh oleh Gallagher et al. (2000), persentase pria yang memiliki persentase lemak tubuh di atas batas normal lebih tinggi dibandingkan dengan wanita.

\section{Tekanan Darah}

Sebagian besar subjek mengalami tekanan darah tinggi yakni sekitar $67.9 \%$ (hipertensi I dan hipertensi II). Tekanan darah tinggi lebih banyak terjadi pada pria dibandingkan wanita yakni pria sekitar $70.0 \%$ dan wanita sekitar $67.2 \%$. Hal tersebut dapat diduga karena adanya peran hormon estrogen pada wanita yang bersifat protektif terhadap vaskular, dimana mungkin wanita dalam penelitian ini tidak semuanya mengalami menopause. Faktor konsumsi makanan tinggi lemak seperti jeroan juga dapat menyebabkan pria lebih banyak yang hipertensi, dimana persentase pria yang sering mengonsumsi jeroan lebih tinggi dibandingkan wanita (Depkes 2008). Sebaran subjek menurut tekanan darah ditampilkan pada Tabel 4. 


\section{Kadar C-Reactive Protein Darah Subjek}

Sebaran subjek menurut kadar CRP darah ditampilkan pada Tabel 5. Nilai median kadar CRP darah subjek secara total adalah $1.6 \mathrm{mg} / \mathrm{L}$ dengan kisaran $0.1-9.3 \mathrm{mg} / \mathrm{L}$. Subjek yang berisiko tinggi penyakit kardiovaskular mencapai $28.4 \%$. Nilai median kadar CRP darah pria $(1.0 \mathrm{mg} / \mathrm{L})$ dengan kisaran $0.1-9.3 \mathrm{mg} / \mathrm{L}$ dan nilai median kadar CRP darah wanita $(2.1 \mathrm{mg} / \mathrm{L})$ dengan kisaran $0.2-9.3 \mathrm{mg} / \mathrm{L}$. Persentase wanita yang berisiko tinggi penyakit kardiovaskular (37.7\%) lebih tinggi dibandingkan dengan pria $(25.0 \%)$.

Persentase Status Gizi Lebih, Hipertensi, dan Kadar CRP Berisiko Penyakit Kardiovaskular

Gambar 1 menunjukkan persentase status gizi lebih, hipertensi, dan kadar CRP berisiko penyakit kardiovaskular pada subjek dalam penelitian ini. Secara umum, subjek dislipidemia cenderung meng- alami kegemukan, hipertensi, dan berisiko penyakit kardiovaskular yang ditandai dengan tingginya persentase status gizi lebih menurut IMT (overweight dan obesitas), LP di atas batas normal, RLPP di atas batas normal, persentase lemak tubuh di atas batas normal, tekanan darah tinggi, dan kadar CRP di atas batas normal (risiko sedang dan tinggi penyakit kardiovaskular).

Wanita dalam penelitian ini lebih cenderung memiliki status gizi lebih (kecuali persentase lemak tubuh), hipertensi, dan kadar CRP berisiko penyakit kardiovaskular yang lebih tinggi dibandingkan pria. Hal ini ditandai dengan persentase wanita yang dominan daripada pria pada status gizi lebih menurut IMT, LP, RLPP, hipertensi, dan kadar CRP yang berisiko penyakit kardiovaskular. Data pada Gambar 1 juga menunjukkan bahwa tidak hanya pria yang mengalami obesitas abdominal, akan tetapi wanita dalam penelitian ini juga obesitas abdominal.

Tabel 4. Sebaran Subjek menurut Tekanan Darah

\begin{tabular}{|c|c|c|c|}
\hline \multirow{2}{*}{ Tekanan Darah } & \multicolumn{2}{|c|}{ Jenis Kelamin } & \multirow{2}{*}{ Total n (\%) } \\
\hline & Pria n (\%) & Wanita n (\%) & \\
\hline Normal & $4(20.0)$ & $7(11.5)$ & $11(13.6)$ \\
\hline Pre-hipertensi & $2(10.0)$ & $13(21.3)$ & $15(18.5)$ \\
\hline Hipertensi I & $8(40.0)$ & $21(34.4)$ & $29(35.8)$ \\
\hline Hipertensi II & $6(30.0)$ & $20(32.8)$ & $26(32.1)$ \\
\hline Total & $20(100.0)$ & $61(100.0)$ & $81(100.0)$ \\
\hline Rata-rata \pm std $(\mathrm{mmHg})^{*}$ & $142 \pm 26 / 86 \pm 14$ & $141 \pm 25 / 89 \pm 13$ & $141 \pm 25 / 89 \pm 13$ \\
\hline
\end{tabular}

Tabel 5. Sebaran Subjek menurut Kadar C-reactive protein Darah

\begin{tabular}{lccc}
\hline \multirow{2}{*}{ C-Reactive Protein } & \multicolumn{2}{c}{ Jenis Kelamin } & \multirow{2}{*}{ Total n (\%) } \\
\cline { 2 - 3 } & Pria n (\%) & Wanita n (\%) & \\
\hline Risiko rendah penyakit kardiovaskular & $9(45.0)$ & $20(32.8)$ & $29(35.8)$ \\
Risiko sedang penyakit kardiovaskular & $6(30.0)$ & $18(29.5)$ & $29(35.8)$ \\
Risiko tinggi penyakit kardiovaskular & $5(25.0)$ & $23(37.7)$ & $23(28.4)$ \\
Median (mg/L) & 1.0 & 2.1 & 1.6 \\
Minimal-maksimal (mg/L) & $0.1-9.3$ & $0.2-9.3$ & $0.1-9.3$ \\
\hline
\end{tabular}

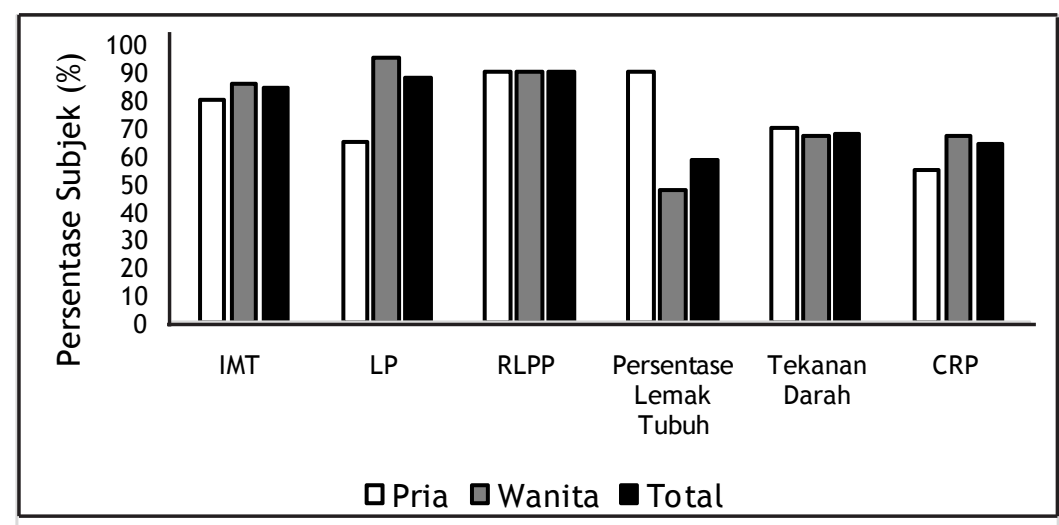

Gambar 1. Persentase Subjek dengan Status Gizi Lebih, Hipertensi, dan Kadar CRP Berisiko Penyakit Kardiovaskular 


\section{Hubungan Status Gizi dan Tekanan Darah terhadap Kadar CRP Darah}

Hasil uji linier berganda menunjukkan bahwa IMT, RLPP, persentase lemak tubuh, dan tekanan diastolik berhubungan positif nyata terhadap kadar CRP darah subjek $(\mathrm{p}<0.05)$, sebaliknya tekanan sistolik berhubungan negatif nyata terhadap kadar CRP darah subjek. LP tidak berhubungan nyata terhadap kadar CRP darah subjek ( $p>0.05$ ).

Hubungan signifikan antara status gizi berdasarkan indikator IMT, RLPP, dan persentase lemak tubuh dalam penelitian ini sesuai dengan beberapa studi lainnya. Studi oleh Khan et al. (2006) menunjukkan bahwa IMT berhubungan signifikan terhadap kadar CRP. Studi lain juga menunjukkan hal demikian, IMT dan RLPP berhubungan signifikan terhadap kadar CRP darah. (Park et al. 2005; Vikram et al. 2006). Lin et al. (2010) menyatakan bahwa persentase lemak tubuh merupakan indikator paling baik dalam menentukan status inflamasi (CRP) terutama pada pria. LP tidak berhubungan nyata dengan kadar CRP darah dalam penelitian ini sesuai dengan hasil studi Lin et al. (2010) bahwa LP bukan indikator yang baik untuk mengindikasikan kenaikan CRP dalam tubuh pada individu yang mengalami kegemukan.

Studi IDEA menunjukkan efek negatif yang diakibatkan kelebihan lemak dengan meningkatnya jaringan lemak viseral (Fox et al. 2009). Lemak abdominal atau viseral secara signifikan meningkatkan indikator-indikator inflamasi (Calabro \& Yeh 2007). Oleh karena itu, risiko inflamasi sistemik lebih tinggi pada individu yang mengalami obesitas abdominal yaitu pada pria.

Kukslinka et al. (2009) menunjukkan bahwa pada individu yang mengalami hipertensi arterial cenderung mengalami kenaikan kadar CRP. Data eksperimental dan hasil studi cross-sectional pada manusia menunjukkan adanya keterkaitan antara CRP dan indikator pengerasan pembuluh arteri sehingga diduga adanya hubungan spesifik antara kadar CRP dan tekanan darah sistolik (Virdis et al. 2007). Akan tetapi, hasil analisis menunjukkan bahwa terdapat hubungan yang negatif antara tekanan darah sistolik dan CRP. Hal ini diduga karena adanya faktor metode pengukuran tekanan darah pada subjek yang hanya dilakukan satu kali saja. Menurut Mancia et al. (2007), pengukuran tekanan darah seseorang untuk mengetahui adanya kenaikan tekanan darah perlu diukur rata-rata tekanan darah sistolik dan diastolik dari beberapa kali pengukuran yang terbagi atas waktu siang dan malam hari. Misalnya cara pengukuran tekanan darah oleh Kukslinka et al. (2009) yang menggunakan acuan Mancia et al. (2007), pengukuran tekanan darah dilakukan pada waktu siang jam $06.00 \mathrm{am}-10.00 \mathrm{pm}$ dengan selang 10 menit dan pada waktu malam jam 10.30 pm-05.40 am dengan selang waktu 20 menit.
Studi Sung et al. (2003) menunjukkan tekanan darah diastolik berhubungan positif nyata terhadap kadar CRP. Hal ini sesuai dengan hasil analisis yang menunjukkan adanya hubungan positif nyata terhadap kadar CRP darah subjek. Menurut JNC VII (2004) tekanan darah diastolik merupakan indikator risiko penyakit kardiovaskular paling kuat dibandingkan dengan tekanan sistolik sebelum usia 50 tahun.

Hubungan tekanan darah terhadap CRP dapat dijelaskan melalui mekanisme yang melibatkan Nitric Oxide (NO). NO merupakan salah satu faktor relaksasi yang dalam kondisi normal berfungsi untuk mencegah agregasi leukosit dan platelet dan menghambat proliferasi sel otot halus vaskular secara lokal. Penurunan ketersediaan NO dapat memengaruhi kondisi protrombotik dan inflamasi dengan peningkatan proliferasi sel otot halus vaskular. Oleh karena kondisi inflamasi menyebabkan disfungsi endotel dan penurunan fungsi endotel NO sintase (eNOS), maka diduga NO merupakan faktor kunci yang menghubungkan inflamasi terhadap hipertensi dan sebaliknya (Boos \& Lip 2006).

\section{KESIMPULAN}

Sebanyak 81 subjek terlibat dalam penelitian ini dan sebagian besar adalah wanita. Rata-rata usia subjek adalah $48 \pm 9$ tahun. Sebagian besar subjek dislipidemia cenderung memiliki status gizi lebih (berdasarkan IMT, LP, RLPP, dan persentase lemak tubuh), mengalami hipertensi, dan berisiko penyakit kardiovaskular. Pada subjek dislipidemia, semakin tinggi IMT, RLPP, persentase lemak tubuh, dan tekanan darah diastolik maka kadar CRP darah akan semakin tinggi. Sebaliknya semakin tinggi tekanan sistolik maka kadar CRP darah akan semakin rendah. Akan tetapi, semakin tinggi LP belum tentu kadar CRP akan semakin tinggi.

Untuk mengurangi risiko penyakit jantung kardiovaskular, individu yang mengalami dislipidemia disarankan untuk tetap menjaga batas IMT, RLPP, persentase lemak tubuh, dan tekanan darah diastolik dalam batas normal agar kadar CRP di dalam tubuh tidak meningkat. Oleh karena itu, diperlukan adanya edukasi untuk meningkatkan kesadaran akan pentingnya aktivitas fisik melalui olahraga seimbang dan pembatasan konsumsi makanan tinggi lemak dan garam. Bagi penelitian selanjutnya yang akan mengambil topik yang sama, verifikasi dari penelitian ini dapat dilakukan dengan menggunakan lebih banyak jenis indikator status gizi dan indikator status inflamasi, seperti interleukin-6 (IL-6) dan TNF-a.

\section{DAFTAR PUSTAKA}

Blake GJ \& Ridker PM. 2003. C-reactive protein and other inflammatory risk markers in acute co- 
ronary syndromes. J Am Coll Cardiol. 41(4s1), S37-S42.

Boos CJ \& Lip GYH. 2006. Is hypertension an inflammatory process?. Current Pharmaceutical Design, 12, 1623-1635.

Calabro P \& Yeh ET. 2007. Obesity, inflammation, and vascular disease: the role of the adipose tissue as an endocrine organ. Subcell Biochem, 42, 63-91.

[Depkes] Departemen Kesehatan RI. 2008. Laporan Riset Kesehatan Dasar [Riskesdas] 2007. Badan Penelitian dan Pengembangan Kesehatan, Kementrian Kesehatan RI, Jakarta.

Fox KAA, Despres JP, Richard AJ, Brette S, \& Deanfield JE. 2009. Does abdominal obesity have a similar impact on cardiovascular disease and diabetes? A study of 91,246 ambulant patients in 27 European countries. Eur Heart J, 30, 3055-3063.

Gallagher D, Heymsfield SB, Heo M, Jebb SA, Murgatroyd PR, \& Sakamoto Y. 2000. Healthy percentage body fat ranges: an approach for developing guidelines based on body mass index. Am J Clin Nutr, 72, 694-701.

Gee M, Mahan KL, \& Stump SE. Weight management. Di dalam: Mahan KL, Stump SE. 2008. editor. Krause's Food and Nutrition Therapy 12th ed. Hal 532-562. Elsevier. Inc, Missouri.

Genest J, Frohlich J, Fodor G, \& McPherson. 2003. Recommendations for management of dyslipidemia and prevention of cardiovascular disease: 2003 update. CMAJ, 168(9), 921-924.

Grundy SM, Cleeman JI, Daniels SR, Donato KA, Eckel RH, Franklin BA, Gordon DJ, Krauss RM, Savage PJ, \& Smith SC. 2005. American Heart Association; National Heart and Blood Institute: Diagnosis and management of the metabolic syndrome: an American heart Association/National Heart, Lung, and Blood Institute Scientific Statement. Circulation, 112(17), 2735-2752.

[JNC VII] Joint National Committee VII. 2004. Prevention, detection, evaluation, and treatment of high blood pressure. National Institute of Health, Rockville (US).

Kahn SE, Zinman B, Haffner SM, O’Neill MC, Kravitz BG, Yu D, Freed MI, Herman WH, Holman RR, \& Jones NP et al. 2006. Obesity is a major determinant of the association of c-reactive protein levels and the metabolic syndrome in type 2 diabetes. Diabetes, 55(8), 2357-2364.

Krummel DA. Medical nutrition therapy for cardiovascular disease. Di dalam: Mahan KL, Stump SE. 2008. editor. Krause's Food and Nutrition Therapy 12th ed. Hal 833-864. Elsevier. Inc, Missouri.

Kuklinska AM, Mroczko B, Musial WJ, Sawicki R, Kozieradzka A, Waszkiewics, \& Szmitkowski
M. 2009. High-sensitivity C-reactive protein and total antioxidant status in patients with essential arterial hypertension and dyslipidemia. Adv in Med Sci, 54(2), 225-232.

Lin CC, Kardia SLR, Li Cl, Liu CS, Lai MM, Lin WY, Chang PC, Lee YD, Chen CC, Lin CH et al. 2010. The relationship of high sensitivity C-reactive protein to percent body fat mass, body mass index, waist-to-hip ratio, and waist circumference in a Taiwanese population. BMC Public Health, 10, 579.

Liu Y, Zhang P, Wang W, Wang H, Ling Z, Wu W, \& Guo X. 2010. The characteristics of dyslipidemia patients with different durations in Beijing: a cross-sectional study. Lipids in Health and Disease, 9, 115.

Mancia G, De Backer G, Dominiczak A. Cifkova R, Fagard R, Germano G, Grassi G, Heagerty AM. Kjeldsen SE, \& Laurent S et al. 2007. The task force for the management of arterial hypertension of the European Society of Hypertension, The task force for the management of arterial hypertension of the European Society of Cardiology. 2007. Guidelines for the management of arterial hypertension: The Task Force for the Management of Arterial Hypertension of the European Society of Hypertension (ESH) and of the European Society of Cardiology (ESC). Eur Heart J, 28(12),1462-536.

[NIH] National Institute of Health. 2001. National cholesterol education program: ATP III guidelines At-A-Glance quick desk reference. NIH Publication No. 01-3305, Rockville (US).

Oparil S, Zaman MA, \& Calhoun DA. 2003. Pathogenesis of hypertension. Ann Intern Med, 139, 761-776.

Papalia DE \& Olds SW. 2001. Human Development, Second Edition. Mc Graw-Hill, USA.

Park HS, Park JY, \& Yu R. 2005. Relationship of obesity and visceral adiposity with serum concentrations of CRP, TNF- $\alpha$, and IL-6. Diabetes Research and Clinical Practice, 69(1), 29-35.

Pearson Thomas A, Mensah George A, Alexander R Wayne, Anderson Jefrrey L, Cannon III Richard O, Criqui Michael, Fadl Yazid Y, Fortmann Stephen P, Hong Yuling, \& Myers Gary L et al. 2003. Markers of inflammation and cardiovascular disease: application to clinical and public health practice. Circulation, 43, 499-511.

Pepys MB \& Hirschfield GM. 2003. C-reactive: a critical update. J Clin Invest, 111, 18051812.

Sung KC, Suh JY, Kim BS, Kang JH, Kim H, Lee MH, Park JR, \& Kim SW. 2003. High sensitivity Creactive protein as an independent risk factor for essential hypertension. American Journal of Hypertension, 16(6), 429-433. 
Dewi dkk.

Vikram NK, Misra A, Dwivedi M, Sharma R, Pandey RM, Luthra K, Chatterjee A, Dhingra V, Jailkhani BL, \& Talwar KK et al. 2003. Correlations of c-reactive protein levels with anthropometric profile, percentage of body fat and lipids in healthy adolescents and young adults in urban North India. Atherosclerosis, 168(2), 305-313.

Virdis A, Ghiadoni L, Plantinga Y, Taddei S, Saivetti A. 2007. C-reactive protein and hypertension: is there a causal relationship? CurT Pharm Des, 13(16), 1693-1698.

[WHO] World Health Organization. 2000. The AsiaPacific perspective: redefining obesity and its treatment. International Diabetes Institute, Melbourne (AU).

2008. Waist circumference and waist-hip ratio. Switzerland, Geneva. 